\title{
Rotifers from Thuy Tien lake and Nhu Y river in central Vietnam, with a description of Ploesoma asiaticum new species (Rotifera: Monogononta)
}

\author{
Mau TRINH DANG, ${ }^{1}$ Hendrik SEGERS,${ }^{2 *}$ La-orsri SANOAMUANG ${ }^{1}$ \\ ${ }^{1}$ Applied Taxonomic Research Center, Department of Biology, Khon Kaen University, 40002 Khon Kaen, Thailand; ${ }^{2}$ Belgian Biodi- \\ versity Platform, Freshwater Laboratory, Royal Belgian Institute for Natural Sciences, Vautierstraat 29, 1000 Brussels, Belgium \\ *Corresponding author: hendrik.segers@naturalsciences.be
}

\begin{abstract}
We surveyed Thuy Tien lake and Nhu Y river, Thua Thien Hue province, Vietnam, for rotifers from March to August 2010, and additionally in February 2012 in Thuy Tien lake. A total of 98 species-level taxa are identified, belonging to 31 genera and 21 families. Of there, 52 are first records for Vietnam, Filinia minuta (Smirnov, 1928) is new to the Oriental region and Ploesoma asiaticum $n$. sp. is new to science. These results increase the rotifer record for Vietnam from 122 to 174 taxa. In addition to describing the new taxon, we provide comparative illustrations including trophi scanning electron microscopy photographs of Ploesoma hudsoni (Imhof 1891).
\end{abstract}

Key words: Biodiversity, freshwater, Southeast Asia, zoogeography.

Received: February 2013. Accepted: June 2013.

\section{INTRODUCTION}

Rotifera, with $c a .2150$ recognised species (Segers, 2008 ) is a group of primary freshwater invertebrates containing two major groups: Monogononta and Bdelloidea. They are widely distributed in inland aquatic habitats and play an important role in freshwater ecosystem functioning. Moreover, they can be used as indicators of water quality (Sladecek, 1983), toxicology test organisms (Arnold et al., 2011), and in aquaculture (Lubzens, 1987; Ogata and Kurokura, 2011). The biology, ecology and systematics of rotifers are reviewed by Wallace et al. (2006).

The state of art of rotifer studies in Southeast (SE) Asia was reviewed by Segers (2001). He concluded that our knowledge of the rotifer fauna of some countries is quite poor (e.g. Brunei, Cambodia and Laos), with less than 10 taxa recorded, while the fauna of Indonesia (ca. 200 taxa), Malaysia (ca. 220 taxa) and, especially, Thailand (ca. 310 taxa) is remarkably better documented. Recently, the study of rotifers from Laos (Segers and Sanoamuang, 2007) and Cambodia (Meas and Sanoamuang, 2008) has raised the number of rotifers recorded for those countries to 130 and 129 taxa, respectively. Thailand remains the country with the best documented rotifer fauna of SE Asia: up to date, there are about 398 taxa recorded from Thailand, with 13 taxa recorded as endemic for Thailand and for the Oriental region (Sa-ardrit et al., present volume).

In contrast to Thailand, our knowledge on the Vietnamese rotifer fauna is quite limited. Studies on rotifers in Vietnam started off with Shirota (1966), who recorded 63 rotifer species in freshwater, brackish, and marine wa- ters from South Vietnam. However, some of these early records are most likely incorrect [e.g. Shirota's illustration of Kellicottia bostoniensis (Rousselet 1908) concerns Kelicottia longispina (Kellicott, 1879): Segers 2001]. Later on, Dang et al. (1980) recorded 52 species of freshwater rotifers, mostly common species. After that followed a long period during which no additional information was published. Recent records are mostly included in more general papers dealing with environment assessments or general plankton studies. Most rotifers recorded from those more recent papers follow Shirota (1966) and Dang et al. (1980), and include Pham and Le (2003; 13 taxa), Nguyen et al. (2004, 2005; 11 taxa, and 34 taxa, no species list, respectively), Ngo et al. (2008; 15 taxa), Duong et al. (2008; 21 taxa). Zhdanova (2011) published the most recent comprehensive study on rotifers from water of reservoirs in Central Vietnam and listed 65 species. Finally, Phan and Le (2012) recorded 49 rotifer species from South Vietnam. Of these, 4 species are reported as new to Vietnam: Asplanchna priodonta Gosse, 1850, Brachionus donneri Brehm, 1951, Conochilus hippocrepis (Schrank, 1803), and Filinia camasecla Myers, 1938. However, A. priodonta had already been recorded by Shirota (1966), the three other are included in $\mathrm{Zh}$ danova (2011). Until now, a total of 122 species of rotifer are recorded from Vietnam.

In order to contribute to the knowledge of the Vietnamese rotifer fauna, we examined the rotifer fauna from Thuy Tien lake and Nhu Y river, Thua Thien Hue province, Vietnam. 


\section{METHODS}

The research was conducted at Thuy Tien lake (latitude: 16.410038, longitude: 107.576591 , area: 6.21 ha, perimeter: $1.75 \mathrm{~km}$ ) and Nhu Y river (latitude: 16.472942 , longitude: 107.598006 , length: $c a .7 \mathrm{~km}$; width: 30-100 m), Thua Thien Hue province, Vietnam (Fig. 1). While Thuy Tien lake is a mesotrophic lake surrounded by mostly forested low hills, Nhu Y river is hypertrophic, and flows through Hue city. We sampled both open water and macrophyte beds in Thuy Tien lake; Nhu Y river does not contain any developed littoral zone. The samples were collected monthly from March to August 2011 in both localities, while Thuy Tien lake was sampled once more in February 2012. Qualitative samples of rotifers were collected from
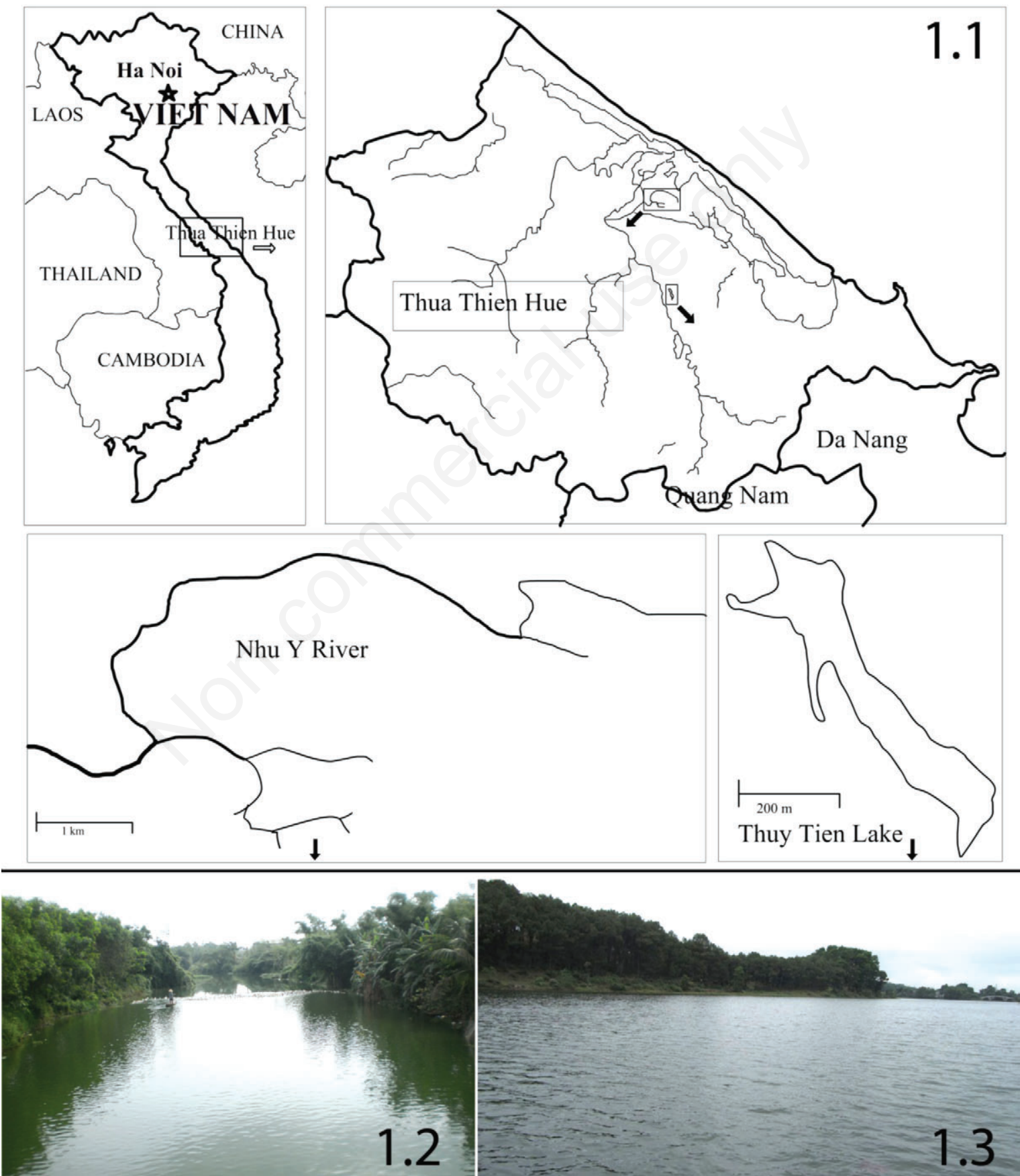

Fig. 1. Study area. 1.1) Schematic maps; 1.2) Nhu Y river; 1.3) Thuy Tien lake. 
the shore, using a hand and cast net with a $50 \mu \mathrm{m}$ mesh size, and were preserved in $4 \%$ formaldehyde. Rotifer specimens were sorted from samples and examined using an Olympus CH 30 compound microscope (Olympus Ltd., Tokyo, Japan). Drawings were made using a camera lucida. Scanning electron microscopy (SEM) was performed on trophi of Ploesoma asiaticum n.sp. and P. hudsoni (Imhof, 1891) with a LEO 1450VP microscope. Trophi were isolated by dissolving tissues using $\mathrm{NaOCl}$. After isolation, trophi were washed by moving the trophi into fresh drops of distilled water, and this process was repeated 4-5 times. Trophi were placed on a circular cover slide ( $1 \mathrm{~cm}$ diameter) and oriented using a fine glass needle. Finally, the trophi were dried and sputter-coated with gold.

The major works used for the identification of rotifers species are: Koste (1978), Koste and Shiel (1987, 1989a, 1989b, 1990), Shiel and Koste (1992), Nogrady et al. (1995), Segers (1995), De Smet and Pourriot (1997), and Nogrady and Segers (2002). We followed the taxonomy and nomenclature of the rotifers as in Segers (2007). Estimates of the rotifer diversity in the sampled habitats were calculated using the EstimateS program (Version 8.2; Colwell, 2013). We constructed species accumulation curves for the sample series of each habitat with 50 randomisations and calculated the Chaol estimator (Chao, 2005 ) and variance using the following formulas:

SChao $1=\mathrm{S}_{\mathrm{obs}}+\mathrm{F}_{1}\left(\mathrm{~F}_{1}-1\right) / 2\left(\mathrm{~F}_{2}+1\right)$

varSChao $1=\mathrm{F}_{1}\left(\mathrm{~F}_{1}-1\right) / 2\left(\mathrm{~F}_{2}+1\right)+\mathrm{F} 1\left(2 \mathrm{~F}_{1}-1\right) 2 / 4$

$\left(\mathrm{F}_{2}+\mathrm{F}_{1}\right) 2+\mathrm{F} 12 \mathrm{~F}_{2}\left(\mathrm{~F}_{1}-1\right) 2 / 4\left(\mathrm{~F}_{2}+1\right) 4$

(eq. 2)

where: $\mathrm{S}_{\mathrm{obs}}$ is the number of species in the pooled samples series; $F_{1}$, the number of singletons; and $F_{2}$, the number of doubletons.

\section{RESULTS}

We identified a total of 98 species-level taxa of rotifers belonging to 31 genera and 21 families. Of them, 49 taxa were recorded from Nhu Y river, and 82 taxa are recorded from Thuy Tien lake. Of there, fifty-two taxa (53.1\%) are new to Vietnam, one species, Filinia minuta (Smirnov, 1928 ) is new to the Oriental region, and one species of Ploesoma is new to science (Tab. 1). A description of the new species and notes on some other interesting species are as follows.

\section{Ploesoma asiaticum new species (Fig. 2)}

Type specimens: holotype (RIR 207) and paratypes (RIR 208-211) in Royal Belgian Institute of Natural Sciences, Brussels, Belgium (RBINS) (IG 32383), two slides containing one paratype each (PSUZC-PK5008-01, 02) in Princess Maha Chakri Sirindhorn Natural History Mu- seum, (PSUNHM), Faculty of Science, Prince of Songkla University, Hat Yai, Songkhla, 90112, Thailand. Some additional unmounted specimens are equally deposited in RBINS.

Type locality: Thuy Tien lake (latitude: 16.410038, longitude: 107.576591), Huong Thuy community, Thua Thien Hue province, Vietnam.

Differential diagnosis: P. asiaticum n. sp. can only be confused with P. hudsoni Imhof, as both are the only Ploesoma species that lack a stiff lorica. The new species can be recognised by its relatively short fulcrum, smaller trophi and body size (Tab. 2), and more conical posterior body shape.

Description (of contracted specimens, head retracted): body relatively soft-loricate, widest in anterior third, conical posteriorly, terminally with a pair of rounded lobes. Foot flexible, annulated, about half body length, with a semirigid terminal pseudosegment of about two thirds toe length; two large, equal toes. A prominent red eyespot pres-
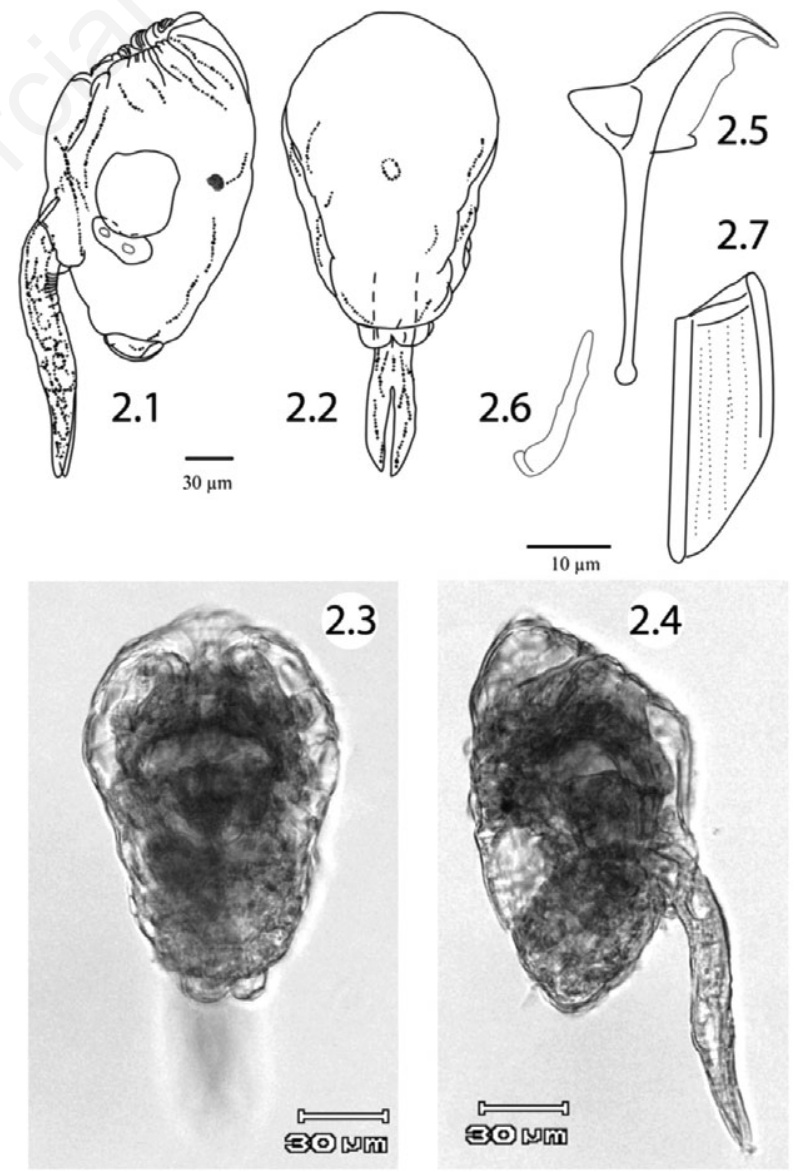

Fig. 2. Ploesoma asiaticum n.sp.: 2.1-4) habitus (2.1 and 2.4 lateral; 2.2 and 2.3 dorsal view, head contracted); 2.5 ) manubrium; 2.6) uncus; 2.7) fulcrum. 
Tab. 1. List of rotifer fauna from Thua Thien Hue province, central Vietnam.

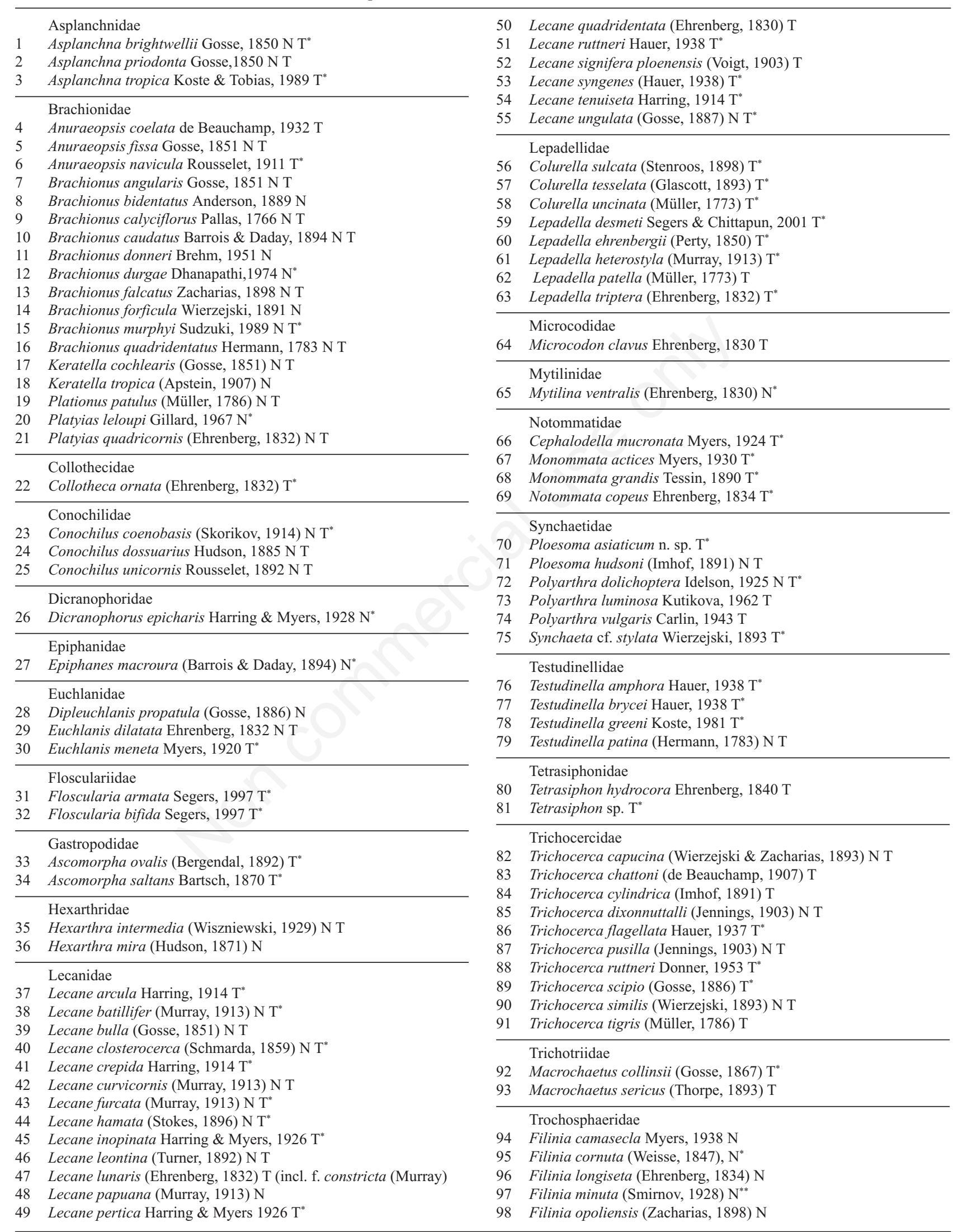

N, Nhu Y river; T, Thuy Tien lake. "New to Vietnam; ${ }^{* *}$ new to Oriental; $n$. sp., new record. 
Tab. 2. Comparison of body and trophi size of $P$. asiaticum and P. hudsoni n.sp.

\begin{tabular}{|c|c|c|c|c|c|}
\hline & \multicolumn{2}{|c|}{ P. asiaticum n.sp. } & \multicolumn{2}{|c|}{ P. hudsoni n.sp. } & \multirow[t]{2}{*}{$t$-test } \\
\hline & Mean \pm SD $(\mu \mathrm{m})$ & n. $(\mu \mathrm{m})$ & Mean \pm SD $(\mu \mathrm{m})$ & n. $(\mu \mathrm{m})$ & \\
\hline \multicolumn{6}{|l|}{ Habitus } \\
\hline Body length & $137.45 \pm 2.73$ & 5 & $193.90 \pm 13.34$ & 5 & $\mathrm{~S}(\mathrm{P}<0.01)$ \\
\hline Body width & $85.21 \pm 1.64$ & 5 & $130.88 \pm 2.51$ & 5 & $\mathrm{~S}(\mathrm{P}<0.01)$ \\
\hline Body heigth & $80.73 \pm 2.81$ & 5 & $141.28 \pm 2.06$ & 5 & $\mathrm{~S}(\mathrm{P}<0.01)$ \\
\hline Foot length & $70.8 \pm 2.65$ & 5 & $103.14 \pm 8.64$ & 5 & $\mathrm{~S}(\mathrm{P}<0.01)$ \\
\hline Toe lenght & $34.26 \pm 1.73$ & 5 & $48.63 \pm 5.58$ & 5 & $\mathrm{~S}(\mathrm{P}<0.01)$ \\
\hline \multicolumn{6}{|l|}{ Trophi } \\
\hline Fulcrum & $28.35 \pm 1.80$ & 5 & $43.19 \pm 1.13$ & 3 & $\mathrm{~S}(\mathrm{P}<0.01)$ \\
\hline Rami & $46.13 \pm 3.43$ & 4 & $51.62 \pm 1.38$ & 3 & $\mathrm{~S}(\mathrm{P}<0.05)$ \\
\hline Manubrium & $51.37 \pm 0.19$ & 4 & $54.25 \pm 4.10$ & 3 & NS \\
\hline
\end{tabular}

SD, standard deviation; $S$, significant; $N S$, not significant.

ent medially. Vitellarium with 4-8 small and round nuclei. Trophi large; manubria (Figs. 2.5, 3.5) with triangular ventral projection and inward-curving dorsal lamella, longer than fulcrum. Unci (Figs. 2.6 and 3.3) single-toothed, with small anterior, submedian triangular projection. Rami (Fig. 3.1-3.4) with finely denticulate inner margins, large double alulae. Fulcrum (Figs. 2.7, 3.6) relatively short, plank-like, with a relatively large anterior expansion in between the rami. Both ventral and dorsal margins reinforced, posterior margin straight, strongly oblique.

Measurements [mean \pm standard deviation (SD), expressed in $\mu \mathrm{m}$; Tab. 2]: length (head contracted): 137.5
(2.7), width: 85.2 (1.7), height: 80.8 (2.8), foot (excluding toes): 70.8 (2.7), toes 34.3 (1.7), fulcrum: 28.4 (1.8), rami: 36.5 (4.1), manubrium: $51.4(0.2)$.

Ecology and distribution: Ploesoma asiaticum n. sp. occurred together with $P$. hudsoni during the rainy season, February, 2012 in Thuy Tien lake. The animal could not be registered in samples collected during the dry season of 2010. Some measurements of environmental characteristics at the time of appearance of $P$. asiaticum n. sp. are: dissolved oxygen (DO) $(\mathrm{mg} / \mathrm{L}): 8.2$; temperature $\left({ }^{\circ} \mathrm{C}\right)$ : 23.4; pH: 5.86; Chl-A: 3.7; total P (mg/L): 0.34; total $\mathrm{N}(\mathrm{mg} / \mathrm{L}): 0.42$.

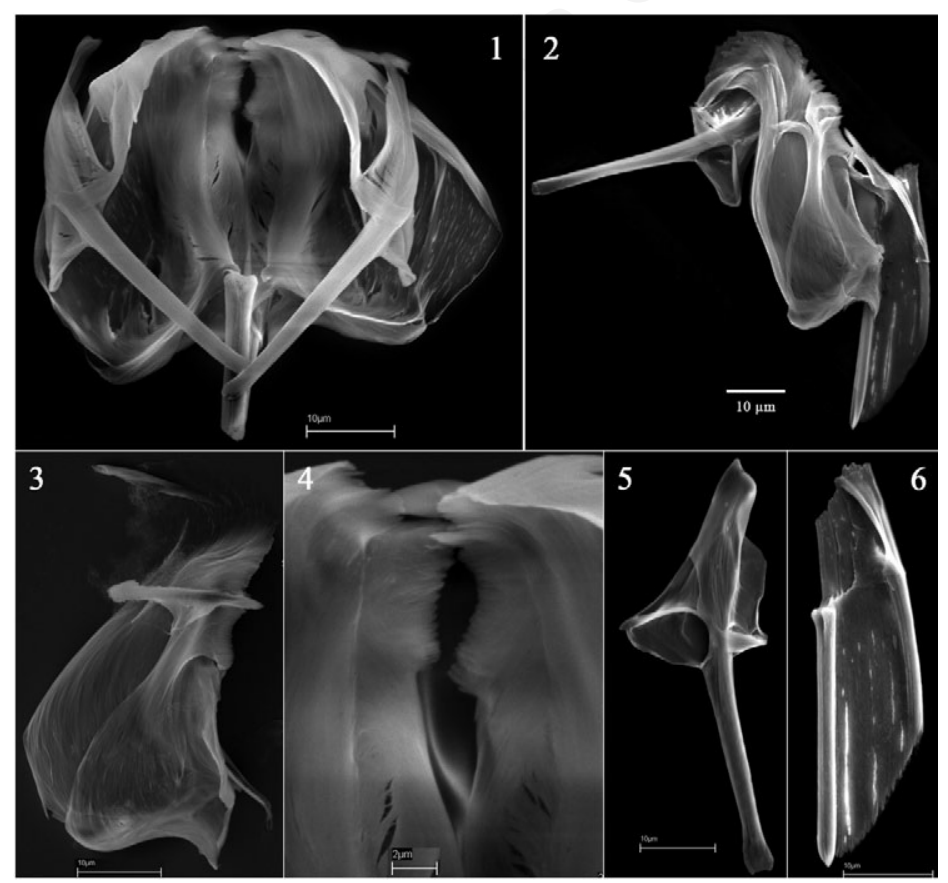

Fig. 3. Ploesoma asiaticum n. sp., trophi scanning electron microscopy: 3.1) dorsal; 3.2) fulcrum, rami and manubrium; 3.3) rami and uncus; 3.4) rami teeth; 3.5) manubrium; 3.6) fulcrum. 
Etymology: the name asiaticum is an adjectival toponym, derived from the geographical region to which the type locality belongs.

\section{Ploesoma hudsoni (Imhof, 1891)}

In contrast to $P$. asiaticum n. sp., $P$. hudsoni was found both in Thuy Tien lake and Nhu Y river during the rainy and the dry season. This species has a semi-stiff lorica, and oval shape. The foot is long and flexible, carrying two large equal toes. The vitellarium has 7-8 ellipsoid nuclei. The fulcrum is only slightly shorter than or as long as the rami, and is plank-shaped in lateral view with only a dorsal reinforced ridge, and curved posterior margin (Figs. 4.6 and 5.2) (Hollowday, 2002). As in P. asiaticum n. sp., the rami curve towards the dorsal side, and bear a median row of small teeth and large double alulae (Fig. 5.1 and 5.2).

\section{Tetrasiphon spp.}

The samples from Thuy Tien lake contained one specimen each of two species belonging to the genus Tetrasiphon. One is identified as T. hydrocora Ehrenberg (Fig. 6.1-6.4 and 6.7-6.9), the second is an undescribed species which is easily characterised by its relatively long fulcrum (Fig. 6.5 and 6.6). It is possible that this animal has been overlooked before as only the species-specific trophi

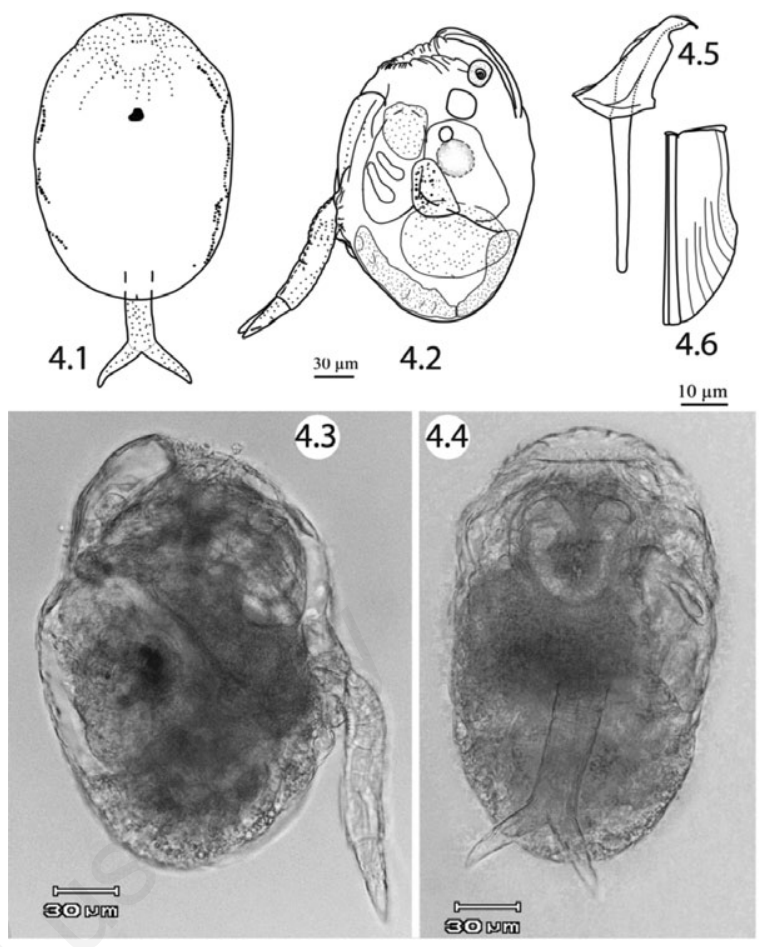

Fig. 4. Ploesoma hudsoni: 4.1-4) habitus (4.1 dorsal; 4.2 and 4.3 lateral; 4.4 ventral, head contracted); 4.5 ) manubrium; 4.6) fulcrum.

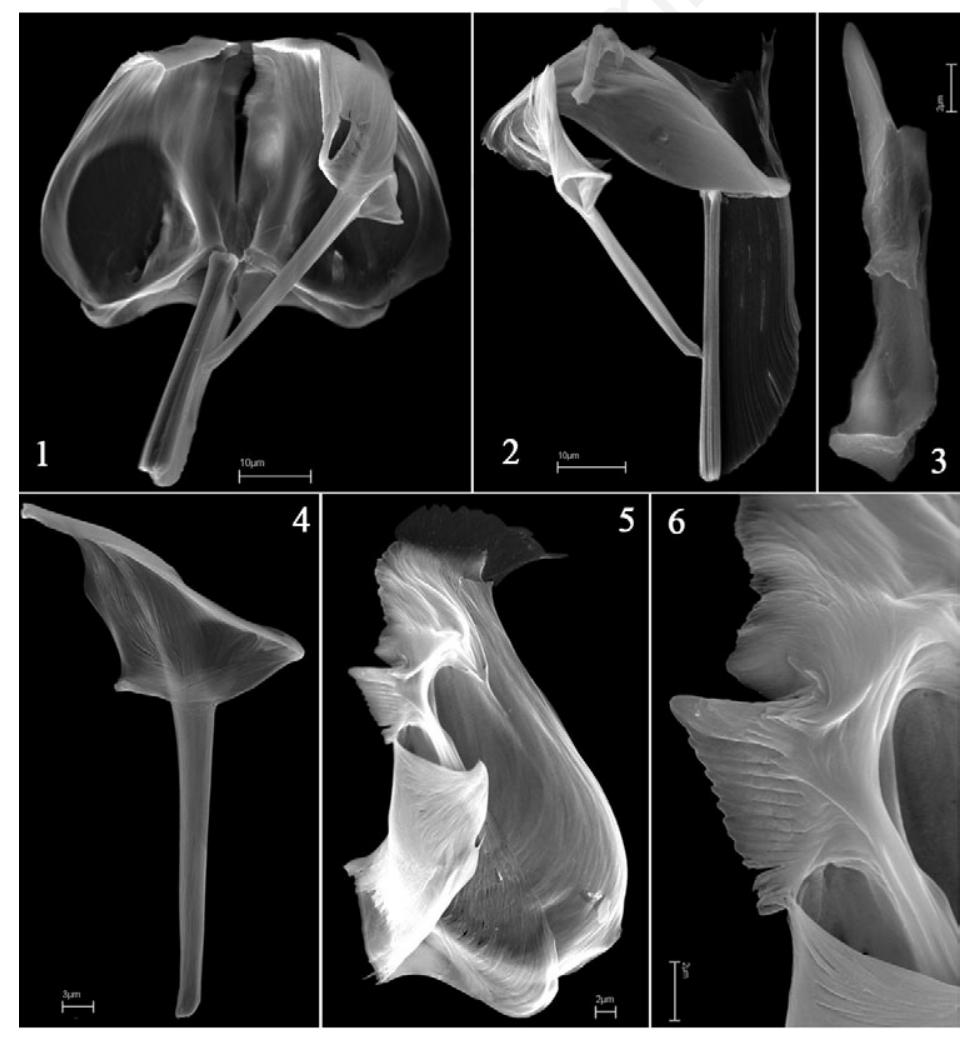

Fig. 5. Ploesoma hudsoni, trophi scanning electron microscopy: 5.1) dorsal view; 5.2) lateral view (fulcrum, rami and manubria); 5.3) uncus; 5.4) manubrium; 5.5) rami; 5.6) rami teeth. 

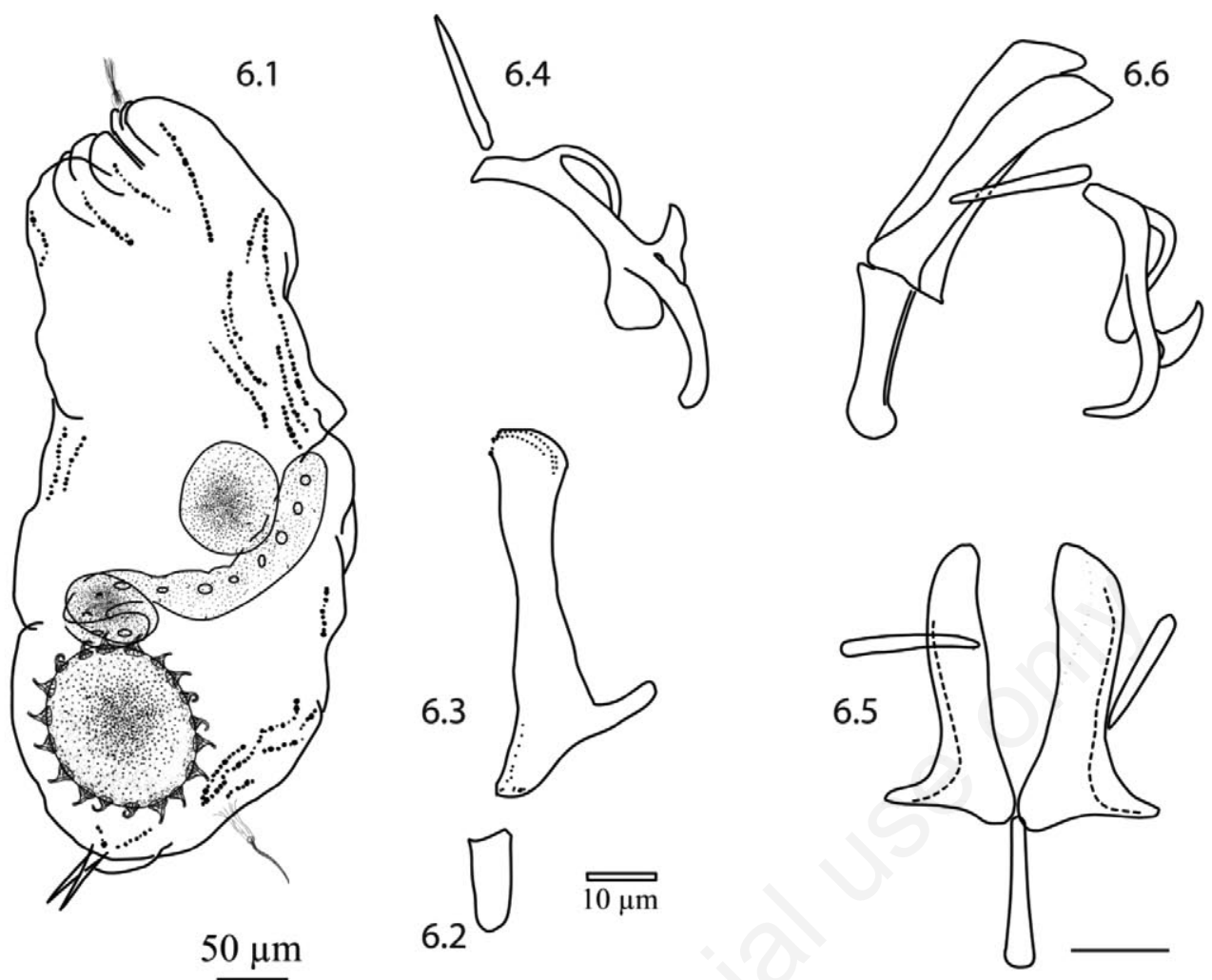

6.3
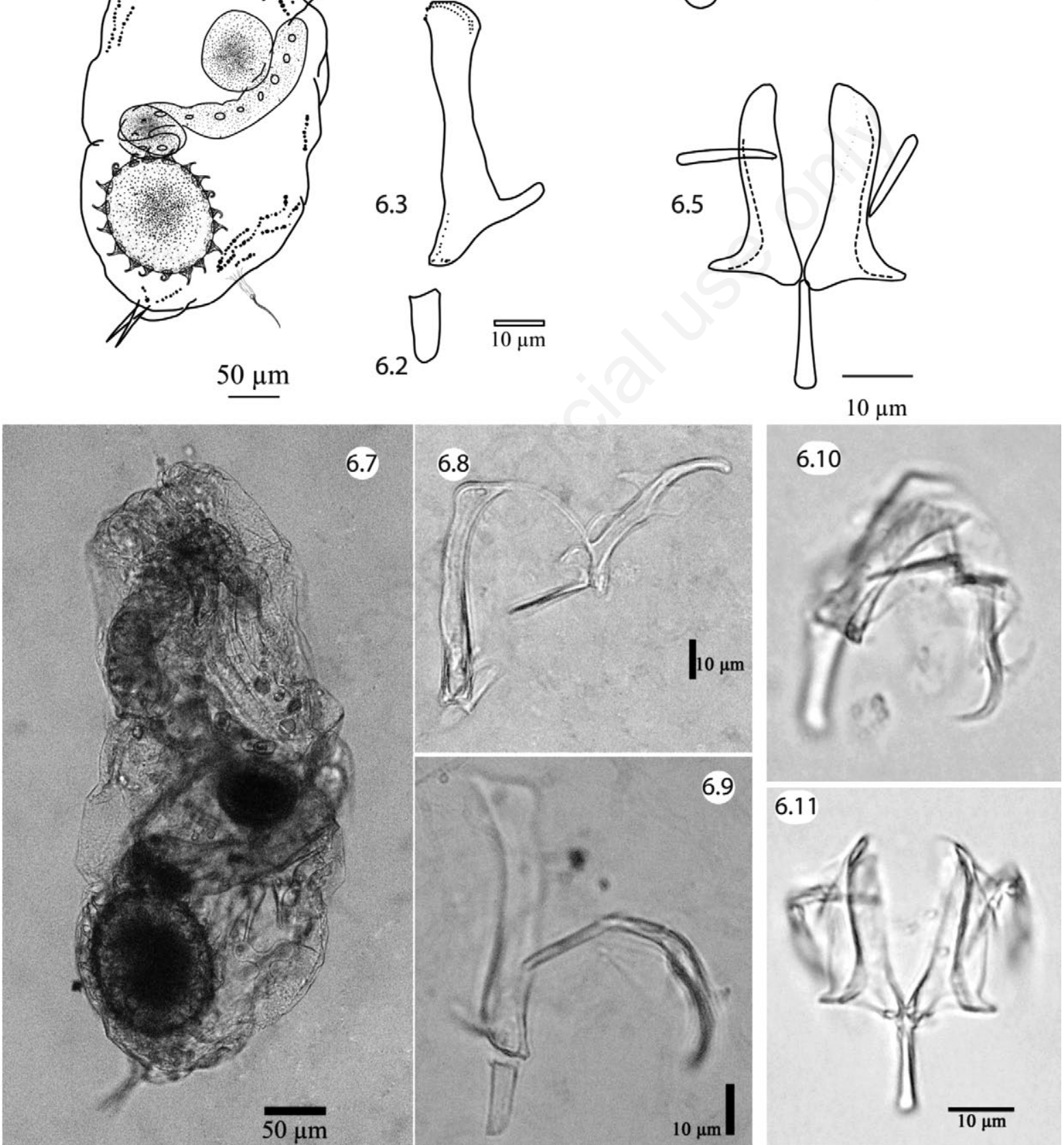

Fig. 6. Tetrasiphon spp.: 6.1 and 6.7) T. hydrocora habitus, lateral view; 6.2-4, 8-9) T. hydrocora trophi; 6.2) fulcrum, lateral view; 6.3) left ramus, frontal view; 6.4) manubrium and uncus, lateral view; 6.8 and 6.9) trophi, different orientations; 6.5, 6.6, 6.10-11) Tetrasiphon sp., trophi; 6.5 and 6.11) ventral view; 6.6 and 6.10) lateral view. 
easily distinguish the two species. We therefore briefly illustrate the two, in particular the undescribed species, for future reference but refrain from formally describing the taxon considering the lack of sufficient material.

\section{Lepadella desmeti Segers and Chittapun, 2001}

We found a single specimen (Fig. 7.1-7.6) of this rare species in Thuy Tien lake. The animal is known from Bolivia (Ichilo river: Segers et al., 1998) and Thailand (Phuket island: Segers and Chittapun, 2001), and has recently been recorded from Hawaii (Jersabek, 2003), Melanesia (Vanuatu: Schabetsberger et al., 2009), and
Austria (Jersabek, 2011). These records indicate that the species may have been overlooked before. Lepadella desmeti can be recognised by its dorsal plate being convex and bearing two pairs of rounded, longitudinal ridges.

\section{Filinia minuta (Smirnov, 1928)}

This species was found in Nhu Y river (Fig. 8). Filinia minuta can not be mistaken for any other Filinia by its small and saccate body, with two antero-lateral and two equal caudal setae. The animal has to date only been recorded from Russia and Japan (Sanoamuang, 2002); the present is therefore the first from the Oriental region.
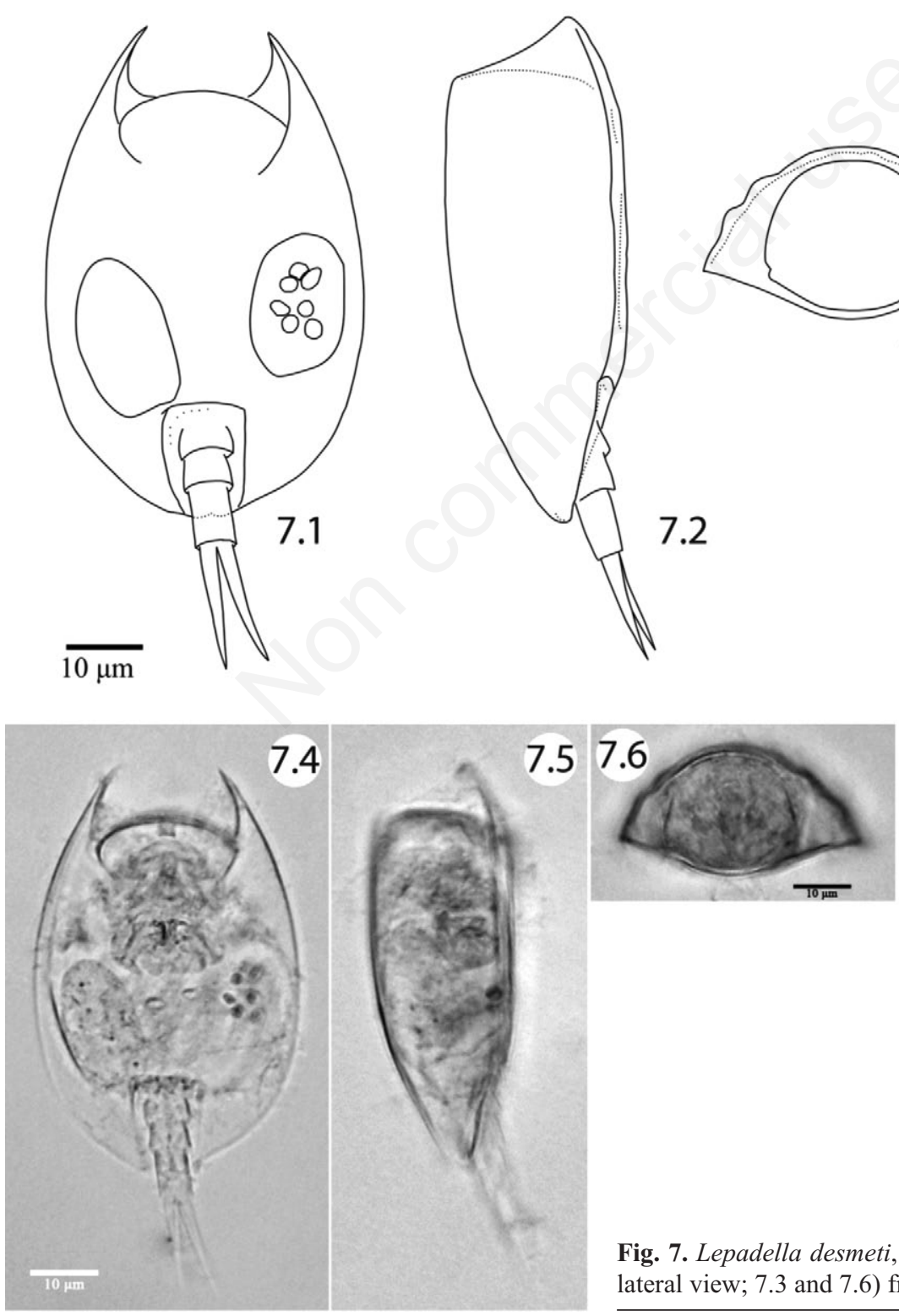

Fig. 7. Lepadella desmeti, habitus. 7.1 and 7.4) ventral view; 7.2 and 7.5) lateral view; 7.3 and 7.6) frontal view. 


\section{Rotifer diversity}

We used the Chaol estimator (Colwell and Coddington, 1994; Dumont and Segers, 1996) to calculate the expected rotifer species diversity in Thuy Tien lake and Nhu $\mathrm{Y}$ river. The result reveals that a diversity of about 122 $(\mathrm{SD}=123.13)$ and about $52(\mathrm{SD}=55.69)$ species can be expected to occur in Thuy Tien lake and Nhu Y river, respectively. The observed $v$ s expected species diversity does not differ greatly in Nhu Y river (49 vs 52), whereas there is a large discrepancy between the two in the case of Thuy Tien lake ( 82 observed $v s 122$ expected). We can therefore assume that our record of rotifers from Nhu Y river is fairly complete, whereas this is not the case for Thuy Tien lake (Fig. 9): indeed, 32 taxa (38.55\%) were found only in a single sample from Thuy Tien lake.

\section{DISCUSSION}

Of 98 species-level taxa identified, Ploesoma asiaticum n. sp. is new to science, Filinia minuta is reported from the Oriental region for the first time, and 52 species are new to Vietnam. All new Vietnam records except Filinia minuta, F. cornuta (Weisse, 1847), Platyias leloupi Gillard, 1967, Polyarthra dolichoptera Idelson, 1925, and Testudinella brycei (Weber, 1898) have been recorded from Thailand. A number of SE Asian endemics: viz. Brachionus donneri Brehm, 1951, B. murphyi Sudzuki 1989, and Filinia camasecla Myers, 1938 (see Segers, 2008) are now also recorded from Central Vietnam. The most diverse genera are Lecane (19 taxa), followed by Trichocerca (10 taxa) and Brachionus (10 taxa), and then Lepadella (5 taxa) and Filinia (5 taxa). Apparently, the species composition of the rotifer fauna of Central Vietnam is quite similar to that of Thailand (Sa-ardrit et al., 2013) and Cambodia (Meas and Sanoamuang, 2008), with Lecane, Trichocerca, Brachionus and Lepadella as most species-rich elements of the fauna. This is not unexpected considering the biogeographical, climatological and ecological similarity of the freshwater habitats of the countries concerned.

Although our research was limited to a small area and only two habitats, we are able to record 98 species, 52 $(53.1 \%)$ of which are new to Vietnam and one is new to science, and which brings to 174 the total number of rotifers recorded from Vietnam. That such a relatively limited effort contributes so significantly to the Vietnamese rotifer record illustrates the rotiferologist effect (Fontaneto et al., 2012), but also that the diversity of the rotifer fauna in Vietnam is potentially much higher than our results indicate. This holds for the two sampled localities as well, in particular for Thuy Tien lake.

The diversity of rotifers from Thuy Tien lake and Nhu $\mathrm{Y}$ river is low in comparison with the estimate of +210 (probably +250 ) spp. that may occur in tropical habitats,
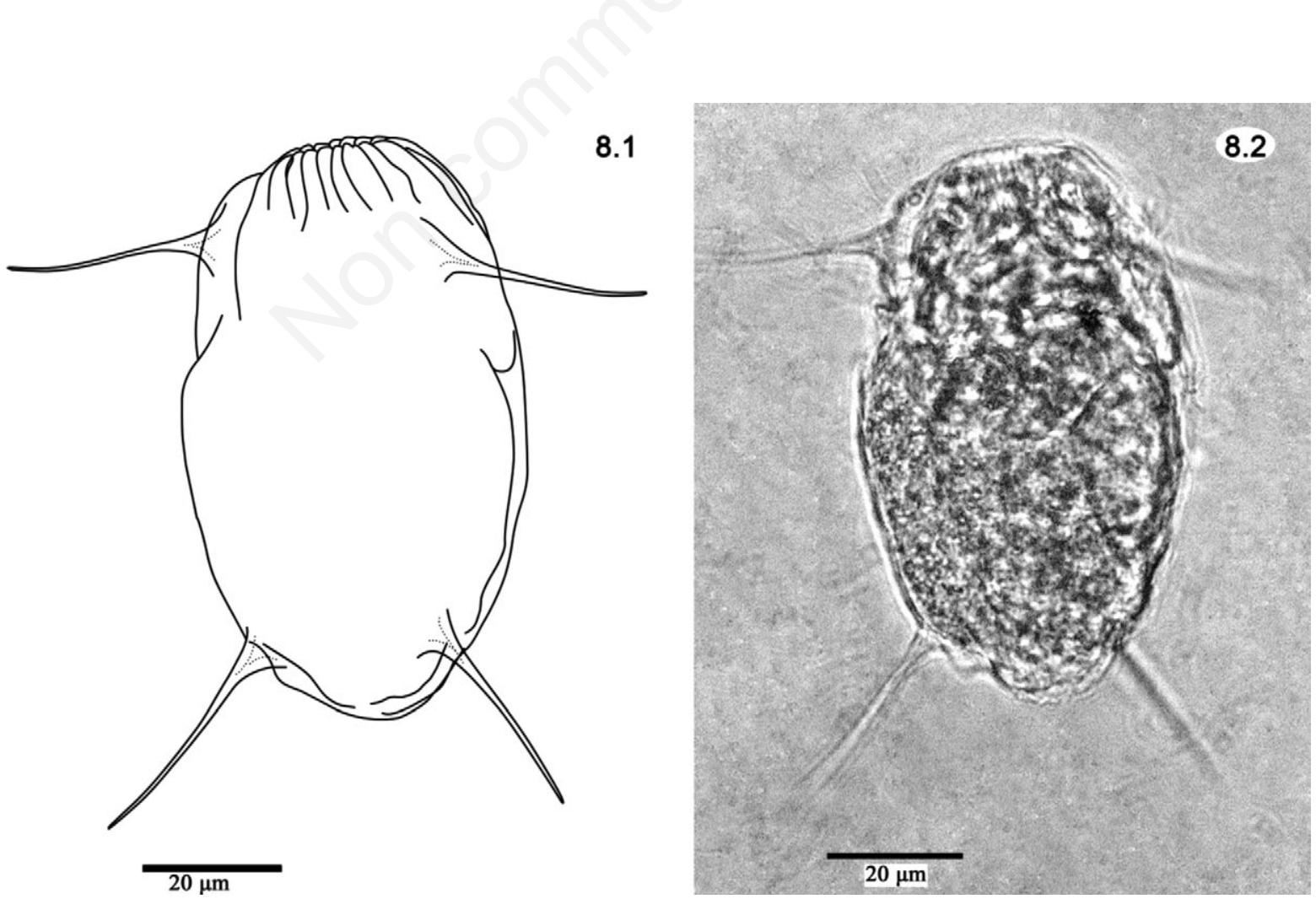

Fig. 8. Filinia minuta, habitus, ventral view. 8.1) drawing; 8.2) photo. 

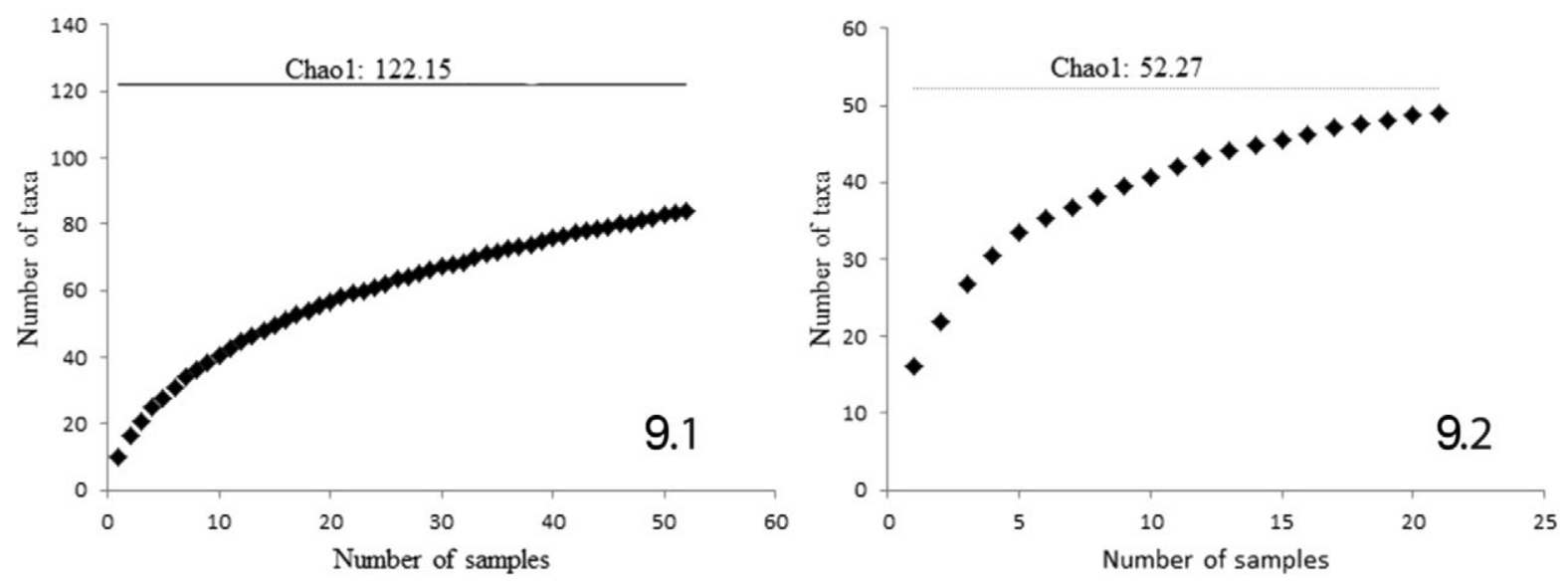

Fig. 9. Species collector curves: 9.1) Thuy Tien lake; 9.2) Nhu Y river.

as reported by Dumont and Segers (1996). Although it should be kept in mind that comparisons of species diversity are difficult in the absence of information on sampling intensity and microhabitats sampled (e.g. benthos, sessile rotifers), our results are at level with the diversity observed from two localities in the floodplain of river Nan, Thailand, with 73 and 86 taxa (Sanoamuang, 1998), but lower than the 106 taxa observed from Thale-Noi lake, Pattalung province, Southern Thailand (Segers and Pholpunthin, 1997), the 183 taxa from Kud-Thing lake, Nong Khai province, Northern Thailand (Sanoamuang and Savatenalinton, 2001), and, in particular, the 135 taxa observed in two samples from a rice paddy and adjacent pond in Laos (Segers and Sanoamuang, 2007).

\section{CONCLUSIONS}

In general, although our results indicate a potentially high rotifers diversity in Vietnam, we must conclude that our knowledge on the Vietnamese rotifers diversity remains relatively poor in comparison with neighbouring countries, in particular Thailand, from which a total of about 400 spp. are recorded (Sa-ardrit et al., 2013). The much higher research intensity in Thailand is most likely a determining factor in this difference, and illustrates that further research on rotifers should be conducted in Vietnam if we wish to obtain a reliable and representative inventory of this country's rotifer fauna.

\section{ACKNOWLEDGMENTS}

We would like to thank the Holistic Watershed Management Research Cluster National Research University Project of Thailand for financial support. We also thank the Applied Taxonomic Research Center, Department of Biology, Faculty of Science, Khon Kaen University, Khon Kaen, Thailand, and the Centre for Coastal Management and Development Studies, Biology Department, Hue University of Science, Vietnam for providing research facility.

Furthermore, we are indebted to the organisers of the Freshwater Invertebrates of Southeast Asia workshop, in particular Prof. Dr. L. Sanoamuang and Dr. Maria K. Hołyńska, for supporting the participation of HS in the conference and the opportunity to present our results.

Finally, we thank three anonymous reviewers for their constructive comments on the manuscript.

\section{REFERENCES}

Arnold WR, Diamond RL, Smith DS, 2011. Acute and chronic toxicity of copper to the euryhaline rotifer, Brachionus plicatilis ("L" strain). Arch. Environ. Con. Tox. 60:250-260.

Chao A, 2005. Species richness estimation, p. 7909-7916. In N. Balakrishnan, C.B. Read, and B. Vidakovic (eds.), Encyclopedia of Statistical Sciences. Wiley Publ.

Colwell RK, 2013. EstimateS: statistical estimation of species richness and shared species from samples. Available from: http://viceroy.eeb.uconn.edu/estimates

Colwell RK, Coddington JA, 1994. Estimating terrestrial biodiversity through extrapolation. Philos. T. Roy. Soc. B 345:101-118.

Dang NT, Thai TB, Pham VM, 1980. [Classification of freshwater invertebrates in Northern Viet Nam]. [Article in Vietnamese]. Science Publishing House, Ha Noi: 573 pp.

De Smet WH, Pourriot R, 1997. Rotifera: the Dicranophoridae (Monogononta) and the Ituridae (Monogononta). SPB Academic Publ., Amsterdam: 318 pp.

Dumont H, Segers H, 1996. Estimating lacustrine zooplankton species richness and complementarity. Hydrobiologia 341:125-132.

Duong ND, Tran NDM, Pham QH, 2008. [Composition of plankton in Lo Go Xa Mat National Park, Tay Ninh Province]. [Article in Vietnamese]. J. Sci. Technol. 7:37-45.

Fontaneto D, Márcia Barbosa A, Segers H, Pautasso M. 2012. The 'rotiferologist' effect and the other global correlates of species richness in rotifers. Ecography 35:174-182. 
Hollowday E, 2002. Family Synchaetidae Hudson \& Gosse, 1886. In: T. Nogrady and H.J. Dumont (eds.), Guides to the identification of the microinvertebrates of the continental waters of the world. SPB Academic Publ., Amsterdam: 211 pp.

Jersabek CD, 2003. Freshwater Rotifera (Monogononta) from Hawai'i: a preliminary checklist, p. 46-72. In: N.L. Evenhuis and L.G. Eldredge (eds.), Records of the Hawaii Biological Survey for 2001-2002, II: notes. Bishop Museum Press. Available from: http://hbs.bishopmuseum.org/pubsonline/pdf/op74.pdf

Jersabek CD, 2011. [Die Rädertiere (Rotifera) des Dösentales (Kärnten)]. [Article in German]. Mitt. Haus der Natur 19:100-102.

Koste W, 1978. [Rotatoria]. [Book in German]. Gebrüder Borntraeger Publ., Berlin: 673 pp.

Koste W, Shiel RJ, 1987. Rotifera from Australian inland waters. II. Epiphanidae and Brachionidae (Rotifera: Monogononta). Invertebr. Taxon. 7:949-1021.

Koste W, Shiel RJ, 1989a. Rotifera from Australian inland waters. III. Euchlanidae, Mytilinidae and Trichotriidae (Rotifera: Monogononta). T. Roy. Soc. South Aust. 113:85-114.

Koste W, Shiel RJ, 1989b. Rotifera from Australian inland waters. IV. Colurellidae (Rotifera: Monogononta). T. Roy. Soc. South Aust. 113:119-143.

Koste W, Shiel RJ, 1990. Rotifera from Australian inland waters. V. Lecanidae (Rotifera: Monogononta). T. Roy. Soc. South Aust. 114:1-36.

Lubzens E, 1987. Raising rotifers for use in aquaculture. Hydrobiologia 147:245-255.

Meas S, Sanoamuang L, 2008. Rotifer communities in the Cambodian Mekong River Basins. KKU. Res. J. 8:18-30.

Ngo TT, Nguyen TH, Le MD, 2008. Composition of plankton in water areas in Gia Lam district, Hanoi. Journal of Science and Technology Ha Noi Agriculture University 6:153-160.

Nguyen XQ, Ngo XN, Bui TV, Tran DA, Dinh VK, 2005. The data on biodiversity of invertebrate from Nhue and Day River and proposed conservation measures, p. 1022-1025. In: Proc. Conf. Issues of basic research in life sciences. Science and Technology Publ.

Nguyen XQ, Ngo XN, Bui TV, Tran DA, Dinh VK, Hoang QK, 2004. Species composition of invertebrates from Van Long - Ninh Binh wetland conservation area, p. 709-711. In: Proc. Conf. Issues of basic research in life sciences. Science and Technology Publ.

Nogrady T, Segers H, 2002. Rotifera: Asplanchnidae, Gastropodidae, Lindiidae, Microcodidiae, Synchaetidae, Trochosphaeridae and Filinia. SPB Academic Publ., Amsterdam: $264 \mathrm{pp}$.

Nogrady T, Pourriot R, Segers H, 1995. Rotifera: the Notommatidae and Scaridiidae. SPB Academic Publ., Amsterdam, $248 \mathrm{pp}$.

Ogata Y, Kurokura H, 2011. Use of the freshwater rotifer Brachionus angularis as the first food for larvae of the Siamese fighting fish Betta splendens. Fisheries Sci. 78:109-112.

Pham VM, Le T, 2003. Research to perfect the biological index for assessing quality, zoning and classification of the waters environment in Ho Chi Minh City. Technology and Environment Publ., Ho Chi Minh City: 26 pp.
Phan DD, Le TNN, 2012. Diversity on rotifera species compatitions in fresh inland waters of Southern Viet Nam and some new records for zooplankton fauna of Viet Nam. Journal of Biology of the Institute of Tropical Biology, Viet Nam 34:13-20.

Sa-ardrit P, Pholpunthin P, Segers H, 2013. A checklist of the freshwater Rotifera fauna of Thailand. 72(Suppl.2):e18.

Sanoamuang L, 1998. Rotifera of some freshwater habitats in the floodplain of the River Nan, Northern Thailand. Hydrobiologia 387/388:27-33.

Sanoamuang L, 2002. Rotifera: genus Filinia. Backhuys Publ., Leiden: $257 \mathrm{pp}$.

Sanoamuang L, Savatenalinton S, 2001. The rotifer fauna of Lake Kud-Thing, a shallow lake in Nong Khai Province, Northeast Thailand. Hydrobiologia 446/447:297-304.

Schabetsberger R, Drozdowski G, Rott E, Lenzenweger R, Jersabek CD, Fiers F, Traunspurger W, Martens K, Reiff N, Schatz H, Stoch F, Kaiser R, Kotov AA, 2009. Losing the bounty? Investigating species richness in isolated freshwater ecosystems of Oceania. Pac. Sci. 63:153-179.

Segers H, 1995. Rotifera: the Lecanidae (Monogononta). SPB Academic Publ., Amsterdam: 225 pp.

Segers H, 2001. Zoogeography of the Southeast Asian Rotifera. Hydrobiologia 446/447:233-246.

Segers H, 2007. Annotated checklist of the rotifers (Phylum Rotifera), with notes on nomenclature, taxonomy and distribution. Zootaxa 1564:1-104.

Segers, H. 2008. Global diversity of rotifers (Rotifera) in freshwater. Hydrobiologia 595:49-59.

Segers H, Chittapun S, 2001. The interstitial Rotifera of a tropical freshwater peat swamp on Phuket Island, Thailand. Belg. J. Zool. 131:65-71.

Segers H, Ferrufino NL, de Meester L, 1998. Diversity and zoogeography of Rotifera (Monogononta) in a flood plain lake of the Ichilo River, Bolivia, with notes on little-known species. Int. Rev. Hydrobiol. 83:439-448.

Segers H, Pholpunthin P, 1997. New and rare Rotifera from Thale-Noi Lake, Pattalang Province, Thailand, with a note on the taxonomy of Cephalodella (Notommatidae). Ann. Limnol.-Int. J. Limnol. 33:13-21.

Segers H, Sanoamuang L, 2007. Note on a highly diverse rotifer assemblage (Rotifera: Monogononta) in a Laotian rice paddy and adjacent Pond. Int. Rev. Hydrobiol. 92:640-646.

Shiel RJ, Koste W, 1992. Rotifera from Australian inland waters. VIII. Trichocercidae (Monogononta). T. Roy. Soc. South Aust. 116:1-27.

Shirota A, 1966. The plankton of South Viet Nam: fresh water and marine plankton. Overseas Technical Corporation Agency ed., Tokyo: 463 pp.

Sladecek V, 1983. Rotifers as indicators of water quality. Hydrobiologia 100:169-201.

Wallace RL, Snell TW, Ricci C, Nogrady T, 2006. Rotifera: biology, ecology and systematics. SPB Academic Publ., The Hague: $142 \mathrm{pp}$.

Zhdanova SM, 2011. The species composition of rotifers in the water reservoirs of Central Viet Nam. Inland Water Biol. 4:425-434. 